\title{
The Association Between Parent Participation in School Management and Student Achievement in Eight Countries and Economies
}

\author{
Jutaro Sakamoto $^{1}$ \\ ${ }^{1}$ College of Education, Michigan State University, East Lansing, United States \\ Correspondence: Jutaro Sakamoto, College of Education, Michigan State University, 620 Farm Lane, East \\ Lansing, MI 48824, United States. E-mail: sakamo12@msu.edu
}

Received: July 7, 2020

doi:10.5539/ies.v14n1p115
Accepted: September 29, 2020

Online Published: December 26, 2020

URL: https://doi.org/10.5539/ies.v14n1p115

\begin{abstract}
Parent participation in school management has been promoted as a strategy for holding schools accountable for education quality and outcomes. However, the evidence has proven inconclusive and limited in explaining mechanisms to affect student achievement. By using public school student data derived from the Programme for International Student Assessment 2015, this study examines how 1) participation of a student's own parents in school management, which would affect their learning support at home and 2) participation of a group of parents, which would influence school decisions and thus affect the learning environment at school, are associated with student achievement in Croatia, Georgia, Portugal, the Dominican Republic, Mexico, Korea, Hong Kong, and Macao. I found no evidence that parent participation in school management contributed to improving student achievement. Instead, depending on the country, a negative association is derived from either individual-level or school-level parent participation. The associations are not moderated by parents' socioeconomic status but by school's openness to parental engagement in some of the countries, indicating that what matters might not be participation per se but the degree of engagement. The findings underscore the importance of understanding mechanisms and conditions in which parent participation affects student learning in context to design effective participatory school governance.
\end{abstract}

Keywords: accountability, parent involvement, school governance, school-based management, student achievement

\section{Introduction}

Governments and development partners confront challenges to secure the rights to quality education. Although the global net enrollment rate in primary and secondary education reached $89 \%$ and $66 \%$ in 2015 respectively (United Nations Educational, Scientific and Cultural Organization [UNESCO] Institute for Statistics, 2018), many countries have failed to provide quality education for an increasing number of students (UNESCO, 2013). Approximately 200 million children and adolescents leave school without learning the basic skills and knowledge that they need to thrive in modern society (UNESCO, 2013).

One of the policy responses to the learning crisis is the decentralization of education governance (Iftene, 2014; Shatkin \& Gershberg, 2007; UNESCO, 2008). By giving decision-making authority to local stakeholders, who are assumed to know their children's educational needs and their local education system better than the central government does, education decentralization is expected to improve the quality of education and hold schools accountable for educational outcomes (Barrera-Osorio, Fasih, \& Patrinos, 2009; UNESCO, 2015b).

In particular, engaging parents in school management is viewed as an important mechanism for improving student achievement because parents have direct incentives to improve their child's education (Barrera-Osorio et al., 2009). For example, parent participation in school management is expected to improve education quality and outcomes by enhancing the transparency of school operations, strengthening accountability for learning outcomes, increasing school resources through local contributions, and achieving a better match between students' learning needs and school offerings (Barrera-Osorio et al., 2009; Bruns, Filmer, \& Patrinos, 2011; Edwards \& DeMatthews, 2014; Moradi, Beidokhti, \& Fathi, 2016). Strengthening school-parent partnerships is recognized as a strategy for addressing the learning crisis and achieving the globally agreed education target in the Sustainable Development Goals: inclusive and equitable quality education for all (UNESCO, 2015a). 
Despite the theoretical underpinnings, the evidence on the association between parent participation in school management and student achievement is inconclusive. In addition, the available evidence does not adequately explain mechanisms by which parent participation influences student achievement. To address the issues, this study pays attention to two mechanisms through which parent participation in school management affects student achievement. First, by participating in school management, individual parents may obtain information about school and build networks with school personnel and other parents that enable them to provide optimal levels of learning support for their child at home. Second, participation provides a group of parents with opportunities to influence school decisions and thus affect the learning environment at school.

Using public school student data derived from the Programme for International Student Assessment (PISA) in 2015, I performed ordinary least squares (OLS) regression analysis to examine how individual-level and school-level parent participation in school management are associated with student achievement and how parents' socioeconomic status (SES) and other factors moderate these associations in eight countries and economies (Croatia, Georgia, Portugal, the Dominican Republic, Mexico, Korea, Hong Kong, and Macao). Understanding mechanisms and conditions in which parent participation affects student achievement in different country contexts provides insight into ways to leverage participatory school governance for improving students' learning.

\section{Parent Participation in School Management and Student Achievement}

\subsection{Empirical Evidence}

There is a fair number of studies that examine the association between parent participation in school management and student achievement. These studies use parent engagement in local school governing bodies, such as parent-teacher associations (PTAs), parent-teacher organizations (PTOs), and school management committees, as a measure of parent participation in school management.

Many empirical studies in the United States exploited rich student-level data to estimate the association between participation of a student's own parents in school management and student achievement. The evidence derived from these studies is mixed. A composite measure of parent involvement in school, which includes participation in a PTA/PTO, was found to be positively associated with student achievement in both cross-sectional and longitudinal studies (Dearing, Kreider, Simpkins, \& Weiss, 2006; Desimone, 1999; Park \& Holloway, 2017). However, other studies found no or negative associations. One longitudinal study found that parent participation in a PTA was not associated with mathematics and reading scores (Domina, 2005). A composite measure of parent participation, which includes PTA/PTO participation, was also identified to have no association or a negative association with student achievement (Fan, 2001; McNeal, 1999; Shumow \& Miller, 2001).

Research exploring the association between parent participation in school management and learning outcomes is also found for less developed countries where school-based management programs have been implemented. These programs transfer the responsibility for school management to local school governing bodies represented by parents. Comparing student achievement between treatment schools and control schools, researchers examined whether school-level parent participation was associated with student achievement. The evidence from these studies is inconclusive. For instance, a positive association was found in Argentina (Galiani, Gertler, \& Schargrodsky, 2008), Ecuador (Ponce, 2006), and Mali (Muskin, 1999), while a lack of association was suggested in studies conducted in Mexico (Santibañez, Abreu-Lastra, \& O'Donoghue, 2014), Nepal (Chaudhury \& Parajuli, 2010), and the Philippines (San Antonio, 2008).

\subsection{Possible Explanation for the Mixed Results}

The literature suggests several conceptual and methodological issues that may have contributed to the mixed evidence.

\subsubsection{Distinction of Parent Participation in School Management}

Parent participation in school management should be distinguished from other types of parent participation because mechanisms to influence student learning differ by type of participation (Epstein, 1995; McNeal, 1999). Although the importance of differentiating types of parent participation has been addressed (Hill \& Taylor, 2004; Shumow \& Miller, 2001), participation in school management is often combined with other types of participation, such as membership in PTAs/PTOs, school visits, volunteering, and fundraising (e.g., Fan, 2001; McNeal, 1999; Sui-Chu \& Willms, 1996). This practice poses a challenge to understand how participation in school management is associated with student achievement.

\subsubsection{Isolation of Individual- and School-Level Parent Participation}

Parent participation in school management is unique in that it influences student learning through two channels. 
First, individual parents who participate in school management could obtain insider information about school, such as curriculum design and instructional/assessment policy, and build networks with school personnel and other parents. These parents may use these resources to provide optimal levels of learning support for their child at home (Hill \& Taylor, 2004; McNeal, 1999), for example, by providing effective homework help and private tutoring. Second, a group of parents participating in school management could influence school decisions and change school policy and practice to improve the learning environment at school (Epstein, 1995). Due to its school-wide influence, this benefit accrues to even students whose parents do not participate in school management as spillover effects.

To understand how parent participation in school management affects student achievement, the association derived from participation of a student's own parents and that of a group of parents needs to be isolated from each other. Park and Holloway (2017) and Sui-Chu and Willms (1996) examined both individual- and school-level parent participation; however, these studies do not provide a clear picture because they used a composite measure of parent participation and/or did not isolate the two associations from each other.

\subsubsection{Heterogeneity in Parents' Socioeconomic Status (SES)}

The literature suggests that parents' SES may moderate the participation-achievement association derived from individual- and school-level parent participation differently. Thus, the role of SES needs to be examined for each of the two mechanisms. With regard to individual-level participation, socioeconomically advantaged parents may have a greater capacity to obtain information and develop networks from their participation and use these advantages in providing more effective learning support at home, although the evidence on the SES advantage is inconclusive (Dearing et al., 2006; Domina, 2005; McNeal, 1999; Park \& Holloway, 2017).

Concerning school-level participation, socioeconomically advantaged parents are reported to have more power to influence school decisions (Chikoko, 2008; Gershberg, Meade, \& Andersson, 2009; Khan, 2003; Swift-Morgan, 2006). However, school-level SES is identified to have zero or negative moderating effects on the participation-achievement association (Park \& Holloway, 2017; Sui-Chu \& Willms, 1996). The literature also suggests that what matters could be a variation in SES within school because, in a socioeconomically diverse school, parent participation creates conflicts within the parent group (Anderson, 1998), which may make it difficult for parents to form a collective power to influence school decisions. In this context, the role of SES as a moderating factor needs to be examined with respect to both the level of and variation in SES.

\subsubsection{Reverse Causality}

Another issue to be addressed is reverse causality, which could generate a downward bias in the participation-achievement association. While parent participation is expected to affect student achievement in theory, poor academic results may provide parents with incentives to increase their involvement in school (McNeal, 2012). Recent studies address this issue by using longitudinal data, which enable researchers to control for past achievement and examine causal directions (Dearing et al., 2006; Domina, 2005).

Overall, the literature suggests the need to examine how individual- and school-level parent participation in school management, each of which would distinctly influence the learning environment, is associated with student achievement and how parents' SES moderates these associations, while addressing reverse causality.

\section{Data}

\subsection{Data and Sample}

This study used data on public school students derived from the PISA 2015 round surveys. The Organisation for Economic Co-operation and Development (OECD) has administered PISA, an international survey assessing the competencies of nationally representative 15 -year-old students, every three years since 2000 . In addition to tests in mathematics, science, and reading, a questionnaire survey was provided to students and their schools. Some countries and economies further administered an optional questionnaire survey to parents of the students. I used only a public school sample because public and private schools, which embody different social values and parental expectations, develop different accountability relationships with parents (Anderson, 1992).

Out of 73 countries and economies that participated in the PISA 2015, 19 countries and economies administered a questionnaire survey to parents. Parents were asked to report whether they "participated in local school government, e.g., parent council or school management committee." The parent-reported participation has missing values accounting for $38.27 \%$ of the sample. Because the test of differences suggested that the missing data are not completely at random, I used a multiple imputation technique to replace missing values with a set of plausible values predicted by other variables in the dataset. I first dropped 11 countries and economies with more than $10 \%$ missing data on parent-reported participation (Note 1) and then performed multiple imputation by chained 
equations to add 20 imputations to the dataset (StataCorp, 2017). The final sample is 31,569 public school students in Croatia, Georgia, Portugal, the Dominican Republic, Mexico, Korea, Hong Kong, and Macao.

\subsection{Student and School Characteristics}

Table 1 presents a descriptive summary of public school students. The detailed description of each variable is provided in Appendix A.

Table 1. Descriptive summary of the public school student sample

\begin{tabular}{|c|c|c|c|c|c|c|c|c|}
\hline \multirow[b]{2}{*}{ Variable } & \multicolumn{8}{|c|}{ Country/Economy } \\
\hline & Croatia & Georgia & Portugal & $\begin{array}{c}\text { Dom. } \\
\text { Republic }\end{array}$ & Mexico & Korea & Hong Kong & Macao \\
\hline \multicolumn{9}{|l|}{ Achievement } \\
\hline Math score & 463.74 & 398.15 & 487.80 & 317.31 & 405.23 & 518.17 & 568.19 & 485.34 \\
\hline Science score & 474.98 & 405.94 & 497.66 & 320.60 & 411.99 & 508.84 & 539.31 & 479.80 \\
\hline Reading score & 486.29 & 396.08 & 495.37 & 344.05 & 418.76 & 509.13 & 537.98 & 462.77 \\
\hline \multicolumn{9}{|l|}{$\underline{\text { Parent participation }}$} \\
\hline Parent-reported participation & 0.19 & 0.25 & 0.12 & 0.61 & 0.48 & 0.14 & 0.10 & 0.26 \\
\hline School-reported participation (\%) & 32.93 & 27.23 & 20.29 & 66.75 & 43.46 & 31.14 & 24.61 & 17.70 \\
\hline \multicolumn{9}{|l|}{ Parent characteristics } \\
\hline Parents' SES & -0.24 & -0.40 & -0.44 & -1.12 & -1.37 & -0.24 & -0.53 & -0.88 \\
\hline \multicolumn{9}{|l|}{$\underline{\text { Student characteristics }}$} \\
\hline Age & 15.71 & 15.87 & 15.78 & 15.74 & 15.81 & 15.70 & 15.75 & 15.85 \\
\hline Female & 0.51 & 0.47 & 0.50 & 0.51 & 0.49 & 0.46 & 0.51 & 0.46 \\
\hline Native immigration status & 0.89 & 0.98 & 0.92 & 0.98 & 0.99 & 1.00 & 0.59 & 0.36 \\
\hline Home/test language match & 0.97 & 0.95 & 0.97 & 0.97 & 0.96 & 1.00 & 0.98 & 0.90 \\
\hline Relative school grade & 0.20 & -0.24 & -0.51 & -0.62 & -0.50 & -0.10 & -0.41 & -0.79 \\
\hline \multicolumn{9}{|l|}{ School program } \\
\hline General & 0.32 & 0.98 & 0.88 & 0.95 & 0.72 & 0.84 & 1.00 & 0.82 \\
\hline Pre-vocational & 0.00 & 0.00 & 0.05 & 0.00 & 0.00 & 0.00 & 0.00 & 0.18 \\
\hline Vocational & 0.68 & 0.02 & 0.07 & 0.05 & 0.28 & 0.16 & 0.00 & 0.00 \\
\hline \multicolumn{9}{|l|}{$\underline{\text { School characteristics }}$} \\
\hline \multicolumn{9}{|l|}{ Location (population) } \\
\hline$<3,000$ & 0.01 & 0.34 & 0.03 & 0.17 & 0.19 & 0.01 & 0.00 & 0.00 \\
\hline $3,000-15,000$ & 0.20 & 0.13 & 0.30 & 0.35 & 0.18 & 0.00 & 0.00 & 0.00 \\
\hline $15,000-100,000$ & 0.41 & 0.16 & 0.50 & 0.29 & 0.20 & 0.12 & 0.00 & 0.00 \\
\hline $100,000-1,000,000$ & 0.35 & 0.16 & 0.14 & 0.11 & 0.21 & 0.38 & 0.00 & 1.00 \\
\hline$>1,000,000$ & 0.03 & 0.21 & 0.03 & 0.07 & 0.21 & 0.48 & 1.00 & 0.00 \\
\hline School size & 605.04 & 636.55 & $1,796.13$ & 650.27 & $1,000.90$ & 947.70 & 797.47 & 522.06 \\
\hline School-mean SES & -0.24 & -0.40 & -0.42 & -1.12 & -1.37 & -0.24 & -0.52 & -0.88 \\
\hline Variation in SES & 0.72 & 0.74 & 0.99 & 0.89 & 0.93 & 0.60 & 0.90 & 0.75 \\
\hline Observations & 5,675 & 4,734 & 6,897 & 3,401 & 6,635 & 3,703 & 403 & 121 \\
\hline
\end{tabular}

Note. The table shows the mean values estimated based on non-imputed data using sampling and replicate weights. The variation in SES is the standard deviation of parents' SES within school.

The average student achievement was highest in Hong Kong and the lowest in the Dominican Republic. Parent-reported participation ranges from 0.10 in Hong Kong to 0.61 in the Dominican Republic. A school-reported proportion of parents who participated in school management was the lowest in Macao at 17.70\%, and the highest in the Dominican Republic at $66.75 \%$. The test scores and parent participation imply that, without controlling for other factors, the participation-achievement association could be a negative one.

\subsection{Differences Between Participating and Non-Participating Parents}

I also examined whether there are any significant differences between parents who did and did not participate in school management. The results of the test of differences are presented in Table 2. 
Table 2. Differences in student and parent characteristics according to parent participation in school management

\begin{tabular}{|c|c|c|c|c|c|c|c|c|}
\hline \multirow[b]{2}{*}{ Variable } & \multicolumn{8}{|c|}{ Test of differences (participating parents - non-participating parents) } \\
\hline & Croatia & Georgia & Portugal & $\begin{array}{c}\text { Dom. } \\
\text { Republic }\end{array}$ & Mexico & Korea & Hong Kong & Macao \\
\hline \multicolumn{9}{|l|}{$\underline{\text { Student characteristics }}$} \\
\hline Age & $\begin{array}{c}-0.06 * * * \\
(0.01)\end{array}$ & $\begin{array}{c}0.00 \\
(0.01)\end{array}$ & $\begin{array}{l}-0.01 \\
(0.01)\end{array}$ & $\begin{array}{c}0.01 \\
(0.01)\end{array}$ & $\begin{array}{c}0.00 \\
(0.01)\end{array}$ & $\begin{array}{c}0.04 * * * \\
(0.01)\end{array}$ & $\begin{array}{c}-0.09 * * * \\
(0.02)\end{array}$ & $\begin{array}{c}0.04 \\
(0.05)\end{array}$ \\
\hline Female & $\begin{array}{c}-0.03 * \\
(0.02)\end{array}$ & $\begin{array}{l}-0.02 \\
(0.02)\end{array}$ & $\begin{array}{l}-0.02 \\
(0.02)\end{array}$ & $\begin{array}{c}0.00 \\
(0.02)\end{array}$ & $\begin{array}{c}-0.03 * \\
(0.02)\end{array}$ & $\begin{array}{l}-0.01 \\
(0.03)\end{array}$ & $\begin{array}{l}-0.03 \\
(0.05)\end{array}$ & $\begin{array}{c}0.05 \\
(0.11)\end{array}$ \\
\hline Native immigration status & $\begin{array}{l}-0.01 \\
(0.01)\end{array}$ & $\begin{array}{l}-0.01 \\
(0.01)\end{array}$ & $\begin{array}{c}0.02 \\
(0.01)\end{array}$ & $\begin{array}{c}0.00 \\
(0.00)\end{array}$ & $\begin{array}{l}-0.01 \\
(0.00)\end{array}$ & $\begin{array}{l}0.00 * \\
(0.00)\end{array}$ & $\begin{array}{l}-0.06 \\
(0.08)\end{array}$ & $\begin{array}{l}-0.07 \\
(0.11)\end{array}$ \\
\hline Home/test language match & $\begin{array}{l}-0.01 \\
(0.01)\end{array}$ & $\begin{array}{c}0.01 \\
(0.01)\end{array}$ & $\begin{array}{l}0.01 * \\
(0.01)\end{array}$ & $\begin{array}{c}0.00 \\
(0.01)\end{array}$ & $\begin{array}{c}-0.02 * * \\
(0.01)\end{array}$ & $\begin{array}{c}0.00 \\
(0.00)\end{array}$ & $\begin{array}{l}-0.03 \\
(0.03)\end{array}$ & $\begin{array}{c}0.04 \\
(0.06)\end{array}$ \\
\hline Relative school grade & $\begin{array}{c}-0.10 * * * \\
(0.01)\end{array}$ & $\begin{array}{c}0.02 \\
(0.03)\end{array}$ & $\begin{array}{l}-0.03 \\
(0.04)\end{array}$ & $\begin{array}{c}0.04 \\
(0.06)\end{array}$ & $\begin{array}{c}-0.12 * * * \\
(0.04)\end{array}$ & $\begin{array}{c}0.02 \\
(0.01)\end{array}$ & $\begin{array}{c}-0.25 * * * \\
(0.06)\end{array}$ & $\begin{array}{l}-0.04 \\
(0.18)\end{array}$ \\
\hline \multicolumn{9}{|l|}{ School program } \\
\hline General & $\begin{array}{l}-0.03 \\
(0.02)\end{array}$ & $\begin{array}{c}0.00 \\
(0.00)\end{array}$ & $\begin{array}{c}-0.05 * * * \\
(0.02)\end{array}$ & $\begin{array}{c}0.00 \\
(0.01)\end{array}$ & $\begin{array}{c}0.05^{* * *} \\
(0.02)\end{array}$ & $\begin{array}{l}-0.01 \\
(0.02)\end{array}$ & - & $\begin{array}{c}0.01 \\
(0.08)\end{array}$ \\
\hline Pre-vocational & - & - & $\begin{array}{c}0.03 * * \\
(0.01)\end{array}$ & - & - & - & - & $\begin{array}{l}-0.01 \\
(0.08)\end{array}$ \\
\hline Vocational & $\begin{array}{c}0.03 \\
(0.02)\end{array}$ & $\begin{array}{c}0.00 \\
(0.00)\end{array}$ & $\begin{array}{c}0.01 \\
(0.01)\end{array}$ & $\begin{array}{c}0.00 \\
(0.01)\end{array}$ & $\begin{array}{c}-0.05 * * * \\
(0.02)\end{array}$ & $\begin{array}{c}0.01 \\
(0.02)\end{array}$ & - & - \\
\hline \multicolumn{9}{|l|}{$\underline{\text { Parent characteristics }}$} \\
\hline Parents' SES & $\begin{array}{c}0.04 \\
(0.03)\end{array}$ & $\begin{array}{l}-0.06 \\
(0.04)\end{array}$ & $\begin{array}{c}0.04 \\
(0.05)\end{array}$ & $\begin{array}{l}-0.01 \\
(0.05)\end{array}$ & $\begin{array}{c}-0.42 * * * \\
(0.05)\end{array}$ & $\begin{array}{c}0.12 * * * \\
(0.03)\end{array}$ & $\begin{array}{c}0.17 \\
(0.14)\end{array}$ & $\begin{array}{l}-0.22 \\
(0.20)\end{array}$ \\
\hline $\begin{array}{l}\text { Reason for school choice: Good } \\
\text { reputation }\end{array}$ & $\begin{array}{c}0.08 * * * \\
(0.03)\end{array}$ & $\begin{array}{c}0.11 * * * \\
(0.03)\end{array}$ & $\begin{array}{c}0.01 \\
(0.03)\end{array}$ & $\begin{array}{c}0.01 \\
(0.02)\end{array}$ & $\begin{array}{c}0.03 \\
(0.02)\end{array}$ & $\begin{array}{c}0.03 \\
(0.03)\end{array}$ & $\begin{array}{c}0.15^{* * *} \\
(0.04)\end{array}$ & $\begin{array}{c}0.09 \\
(0.18)\end{array}$ \\
\hline $\begin{array}{l}\text { Reason for school choice: } \\
\text { Courses offered }\end{array}$ & $\begin{array}{l}0.05^{*} \\
(0.03)\end{array}$ & $\begin{array}{l}0.10^{*} \\
(0.05)\end{array}$ & $\begin{array}{l}0.06^{* *} \\
(0.03)\end{array}$ & $\begin{array}{l}-0.02 \\
(0.04)\end{array}$ & $\begin{array}{c}0.06^{* * *} \\
(0.02)\end{array}$ & $\begin{array}{c}0.21 * * * \\
(0.04)\end{array}$ & $\begin{array}{l}0.34 * * \\
(0.13)\end{array}$ & $\begin{array}{l}0.40^{* *} \\
(0.18)\end{array}$ \\
\hline $\begin{array}{l}\text { Reason for school choice: High } \\
\text { achievement }\end{array}$ & $\begin{array}{l}0.08 * * \\
(0.03)\end{array}$ & $\begin{array}{c}0.10 * * * \\
(0.03)\end{array}$ & $\begin{array}{l}-0.02 \\
(0.03)\end{array}$ & $\begin{array}{l}0.06 * * \\
(0.03)\end{array}$ & $\begin{array}{c}0.01 \\
(0.02)\end{array}$ & $\begin{array}{c}0.10 * * \\
(0.04)\end{array}$ & $\begin{array}{l}-0.02 \\
(0.09)\end{array}$ & $\begin{array}{r}0.34^{* *} \\
(0.15)\end{array}$ \\
\hline Satisfaction with school quality & $\begin{array}{c}0.15^{* * *} \\
(0.04)\end{array}$ & $\begin{array}{c}0.42 * * * \\
(0.04)\end{array}$ & $\begin{array}{c}0.16^{* * *} \\
(0.04)\end{array}$ & $\begin{array}{c}0.12 * * \\
(0.05)\end{array}$ & $\begin{array}{c}0.20 * * * \\
(0.03)\end{array}$ & $\begin{array}{c}0.25 * * * \\
(0.05)\end{array}$ & $\begin{array}{c}0.59 * * * \\
(0.07)\end{array}$ & $\begin{array}{c}0.18 \\
(0.25)\end{array}$ \\
\hline Observations & 5,229 & 4,475 & 6,394 & 3,188 & 6,045 & 3,630 & 397 & 117 \\
\hline
\end{tabular}

Note. The table shows coefficients and standard errors in parentheses for the test of differences between parents who did and did not participate in school management based on non-imputed data. Sampling and replicate weights are used for estimation. Significance level: * $\mathrm{p}<0.10 ; * * \mathrm{p}<0.05 ; * * * \mathrm{p}<0.01$.

With regard to student characteristics, parents of children enrolled in lower grades were more likely to participate in school management in Croatia, Mexico, and Hong Kong only. In terms of parent characteristics, parents who participated in school management had lower SES in Mexico but higher SES in Korea. More consistent differences are identified in parents' academic orientation and their satisfaction with school. Parents were asked to rate the importance of school reputation, offering of particular courses, and school academic achievement in choosing their child's school. These questions indicate the degree to which parents care about the quality of education and their child's academic success. The results show that participating parents were more likely to value at least one of the academic orientation measures in all the countries and economies. In addition, they had a higher level of satisfaction with the quality of their child's school than non-participating parents except Macao.

\section{Methods}

\subsection{Basic Model}

I estimated OLS regression models to examine the relationship between parent participation in school management and student achievement for each of the countries and economies. All models were estimated by using sampling weights and balanced repeated replication weights to obtain estimates that account for the complex survey design of PISA (OECD, 2017a, 2017b). The basic model is specified below.

$$
\text { Score }_{i s}=\beta_{0}+\beta_{1} \text { Participation }_{i s}+\beta_{2} \% \text { Participation }_{s}+\beta_{3} \text { SES }_{i s}+\text { STUcharacter }_{i s} \beta_{4}+\text { SCHcharacter }_{s} \beta_{5}+
$$




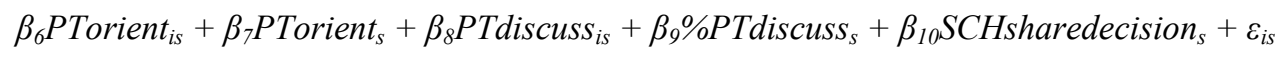

The outcome (Score) is a PISA test score in mathematics, science, or reading of student $i$ in school $s$ (Note 2). The student performance is scaled to have an OECD mean of 500 and standard deviation of 100 . The outcome is estimated as a function of individual- and school-level parent participation in school management. Participation of a student's own parents (Participation) is derived from parents' self-reporting on whether they participated in local school government. School-level parent participation (\%Participation) is measured by the school-reported proportion of parents who participated in local school government. This study used the school-reported measure, rather than aggregating parent-reported participation to school level, due to the relatively large proportion of missing data in the latter variable. The school-reported participation measure would also capture the participation of parents who were not sampled for the survey.

The model controlled for parents' SES (SES) and student characteristics that affect test scores (STUcharacter), including age, gender, native immigration status, home-school language match, school grade, and school program enrolled. School characteristics (SCHcharacter) include school location and size.

The parameter estimates for parent participation are biased if the participation measures are endogenous to other unobserved factors that are correlated with both parent participation and student achievement. Although an instrumental variable approach would be an option to address the endogeneity in cross-sectional data, no valid instruments are found in the data. Thus, I decided to include several additional variables to control for potential sources of endogeneity.

First, I controlled for parents' academic orientation, which could result in an upward bias in the participation-achievement associations. Parents who participate in school management may have higher expectations for their child's academic success, which may affect the child's learning behavior and achievement. To address the issue, I used factor analysis to generate latent variables that measure the degree of the parents' academic orientation from a set of questions asking parents the importance of education quality for choosing their child's school. The first factor, which accounts for $58 \%$ of the total variation, was used as a control for the

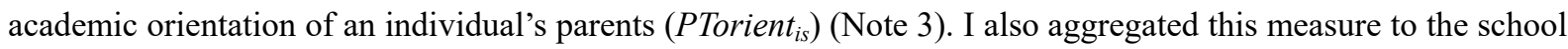
level as a school-mean parents' academic orientation (PTorient $t_{s}$ ) that may affect both school-level parent participation and student achievement.

Second, the model addressed the aforementioned reverse causality. The reverse causality happens when parents of poorly performing children decide to participate in school management to improve the school learning environment for their child. Similarly, school-level parent participation may be high in low-performing schools if parents in such schools try to participate in school management to improve their schools' learning environment. These behavioral patterns would create a downward bias. I assume that such parents would talk to teachers of their child before thinking of participating in school management if they have concerns over their child's performance. In the PISA survey, parents reported whether they took the initiative in discussing their child's progress with a teacher (PTdiscuss). Schools also reported the proportion of parents who took the initiative to discuss their child's progress with a teacher (\%PTdiscuss). I used the two measures as a control for parents' behavior to participate in school for the purpose of improving academic achievement of their low-performing child and school.

Third, the model controlled for whether the school involved parents in school decision-making (SCHsharedecision). Schools involving parents in decision-making might not only facilitate parent participation but also offer academically oriented programs to satisfy parents' expectations and/or attract high-achieving students. This could result in upward bias. To address this issue, I included schools' self-reported information on whether they involved parents in decision-making in the models. The detailed description of each variable is provided in Appendix A.

\subsection{Interaction Models}

Next, this study examined whether parents' SES moderates the participation-achievement association. First, I examined whether SES of an individual's parents moderates the association between participation of the student's parents and that student's achievement. In model 2, individual-level parent participation is interacted with parents' SES. The parameter estimate $\left(\beta_{11}\right)$ indicates whether the association between participation of a student's own parents and their child's achievement differs according to the parent's SES.

$$
\begin{aligned}
& \text { Score }_{i s}=\beta_{0}+\beta_{1} \text { Participation }_{\text {is }}+\beta_{2} \% \text { Participation }_{s}+\beta_{3} \text { SES }_{i s}+\text { STUcharacter }_{i s} \beta_{4}+\text { SCHcharacter }_{s} \beta_{5}+
\end{aligned}
$$

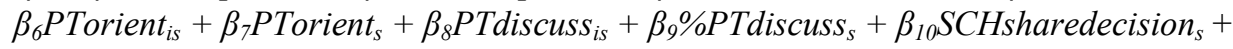

$$
\begin{aligned}
& \beta_{11}\left(\text { Participation }_{\text {is }} \times S E S_{i s}\right)+\varepsilon_{i s}
\end{aligned}
$$

Second, I examined whether school-mean parents' SES (SCHSES), as a source of bargaining power, moderates the 
association between school-level parent participation and student achievement. In model 3, school-level parent participation is interacted with a school-average SES, which is included as both a main effect and an interaction effect.

$$
\begin{aligned}
& \text { Score }_{i s}=\beta_{0}+\beta_{1} \text { Participation }_{\text {is }}+\beta_{2} \% \text { Participation }_{s}+\beta_{3} \text { SES }_{i s}+\text { STUcharacter }_{i s} \beta_{4}+\text { SCHcharacter }_{s} \beta_{5}+ \\
& \beta_{6} \text { PTorient }_{i s}+\beta_{7} \text { PTorient }_{s}+\beta_{8} \text { PTdiscuss }_{i s}+\beta_{9} \% \text { PTdiscuss }_{s}+\beta_{10} \text { SCHsharedecision }_{s}+ \\
& \beta_{11} \text { SCHSES }_{s}+\beta_{12}\left(\% \text { Participation }_{s} \times \text { SCHSES }_{\mathrm{s}}\right)+\varepsilon_{i s}
\end{aligned}
$$

Third, I examined whether a within-school variation in SES (SDSES), which is measured by the standard deviation in parents' SES in school $s$, moderates the association between school-level parent participation and student achievement. In model 4, the within-school SES variation is included as a main effect and an interaction effect.

$$
\begin{aligned}
& \text { Score }_{i s}=\beta_{0}+\beta_{1} \text { Participation }_{i s}+\beta_{2} \% \text { Participation }_{s}+\beta_{3} \text { SES }_{i s}+\text { STUcharacter }_{i s} \beta_{4}+\text { SCHcharacter }_{s} \beta_{5}+ \\
& \beta_{6} \text { PTorient }_{i s}+\beta_{7} \text { PTorient }_{s}+\beta_{8} \text { PTdiscuss }_{i s}+\beta_{9} \% \text { PTdiscuss }_{s}+\beta_{10} \text { SCHsharedecision }_{s}+ \\
& \beta_{11} \text { SDSES }_{s}+\beta_{12}\left(\% \text { Participation }_{s} \times S D S E S_{s}\right)+\varepsilon_{i s}
\end{aligned}
$$

\begin{tabular}{|c|c|c|c|c|c|c|c|c|}
\hline \multirow[b]{2}{*}{ Parent participation } & \multicolumn{8}{|c|}{ Test score } \\
\hline & Croatia & Georgia & Portugal & $\begin{array}{c}\text { Dom. } \\
\text { Republic }\end{array}$ & Mexico & Korea & Hong Kong & Macao \\
\hline \multicolumn{9}{|l|}{ Math } \\
\hline Parent-reported participation & $\begin{array}{c}-10.80 * * * \\
(3.20)\end{array}$ & $\begin{array}{l}-1.20 \\
(3.60)\end{array}$ & $\begin{array}{l}-1.80 \\
(4.11)\end{array}$ & $\begin{array}{c}-7.51 * * \\
(3.11)\end{array}$ & $\begin{array}{l}-1.34 \\
(2.40)\end{array}$ & $\begin{array}{l}-6.18 \\
(5.22)\end{array}$ & $\begin{array}{c}9.30 \\
(14.40)\end{array}$ & $\begin{array}{c}5.99 \\
(20.01)\end{array}$ \\
\hline $\begin{array}{l}\text { School-reported } \\
\text { participation (\%) }\end{array}$ & $\begin{array}{c}0.00 \\
(0.07)\end{array}$ & $\begin{array}{c}-0.26^{* * *} \\
(0.09)\end{array}$ & $\begin{array}{l}-0.08 \\
(0.07)\end{array}$ & $\begin{array}{c}0.06 \\
(0.08)\end{array}$ & $\begin{array}{c}0.04 \\
(0.06)\end{array}$ & $\begin{array}{c}0.10 \\
(0.08)\end{array}$ & $\begin{array}{c}0.14 \\
(0.31)\end{array}$ & $\begin{array}{l}-1.76 \\
(4.13)\end{array}$ \\
\hline \multicolumn{9}{|l|}{ Science } \\
\hline Parent-reported participation & $\begin{array}{c}-10.35 * * * \\
(2.79)\end{array}$ & $\begin{array}{l}-5.70^{*} \\
(3.06)\end{array}$ & $\begin{array}{l}-4.52 \\
(3.83)\end{array}$ & $\begin{array}{c}-7.84 * * * \\
(2.82)\end{array}$ & $\begin{array}{l}-4.25^{* *} \\
(2.03)\end{array}$ & $\begin{array}{l}-6.71 \\
(4.80)\end{array}$ & $\begin{array}{c}7.46 \\
(14.38)\end{array}$ & $\begin{array}{c}2.35 \\
(18.80)\end{array}$ \\
\hline $\begin{array}{l}\text { School-reported } \\
\text { participation (\%) }\end{array}$ & $\begin{array}{c}0.00 \\
(0.06)\end{array}$ & $\begin{array}{l}-0.18^{* *} \\
(0.08)\end{array}$ & $\begin{array}{l}-0.01 \\
(0.05)\end{array}$ & $\begin{array}{c}0.04 \\
(0.07)\end{array}$ & $\begin{array}{c}0.03 \\
(0.05)\end{array}$ & $\begin{array}{c}0.14 \\
(0.08)\end{array}$ & $\begin{array}{c}0.09 \\
(0.26)\end{array}$ & $\begin{array}{l}-0.52 \\
(3.16)\end{array}$ \\
\hline \multicolumn{9}{|l|}{ Reading } \\
\hline Parent-reported participation & $\begin{array}{c}-11.11 * * * \\
(3.11)\end{array}$ & $\begin{array}{l}-5.12 \\
(3.84)\end{array}$ & $\begin{array}{l}-3.75 \\
(3.93)\end{array}$ & $\begin{array}{c}-7.94 * * \\
(3.49)\end{array}$ & $\begin{array}{l}-4.61 * \\
(2.39)\end{array}$ & $\begin{array}{l}-9.21 * \\
(4.88)\end{array}$ & $\begin{array}{c}4.48 \\
(15.64)\end{array}$ & $\begin{array}{c}-9.08 \\
(19.47)\end{array}$ \\
\hline $\begin{array}{l}\text { School-reported } \\
\text { participation (\%) }\end{array}$ & $\begin{array}{c}0.00 \\
(0.08)\end{array}$ & $\begin{array}{l}-0.21 * * \\
(0.10)\end{array}$ & $\begin{array}{l}-0.01 \\
(0.07)\end{array}$ & $\begin{array}{l}-0.01 \\
(0.08)\end{array}$ & $\begin{array}{c}0.03 \\
(0.06)\end{array}$ & $\begin{array}{c}0.12 \\
(0.08)\end{array}$ & $\begin{array}{c}0.08 \\
(0.24)\end{array}$ & $\begin{array}{l}-2.09 \\
(3.45)\end{array}$ \\
\hline Observations & 5,675 & 4,734 & 6,897 & 3,401 & 6,635 & 3,703 & 403 & 121 \\
\hline
\end{tabular}

\section{Results}

\subsection{Association Between Parent Participation and Student Achievement}

Table 3 presents the association between parent participation in school management and student achievement estimated by the basic regression model.

Table 3. Association between parent participation in school management and student achievement

Note. The table shows coefficients for individual- and school-level participation and their standard errors in parentheses. Significance level: * $\mathrm{p}<0.10 ; * * \mathrm{p}<0.05 ; * * * \mathrm{p}<0.01$.

The results show that participation of a student's own parents is not significantly associated with student achievement at the 5\% significance level in the majority of countries and economies except for Croatia, the Dominican Republic, and Mexico. On average, participation of a student's own parents is associated with a decrease in test scores in mathematics, science, and reading in Croatia (-11 points) and the Dominican Republic (-8 points) and a reduction in science scores in Mexico (-4 points).

Similarly, school-level parent participation is not statistically significantly associated with student achievement in most of the countries and economies. An exception is Georgia, where a 10-percentage-point increase in the proportion of parents who participate in school management is associated with a decrease in test scores in mathematics, science, and reading by about two points.

Overall, I found no evidence that parent participation in school management contributed to improving student achievement. The participation-achievement association varies by country and economy, but any statistically significant associations lie in a negative direction. However, depending on the country and economy, the negative 
association is derived from different mechanisms, that is, either participation of a student's own parents or participation of a group of parents.

\subsection{Roles of Parents'SES as a Moderating Factor}

Table 4 summarizes the results of interaction regression models that examined whether parents' SES moderates the participation-achievement association.

Table 4. Interaction effects between parent participation in school management and SES

\begin{tabular}{|c|c|c|c|c|c|c|c|c|}
\hline \multirow[b]{2}{*}{ Interaction term } & \multicolumn{8}{|c|}{ Test score } \\
\hline & Croatia & Georgia & Portugal & $\begin{array}{c}\text { Dom. } \\
\text { Republic }\end{array}$ & Mexico & Korea & Hong Kong & Macao \\
\hline \multicolumn{9}{|c|}{$\begin{array}{l}\text { Individual-level participation } \times \\
\text { parents' SES }\end{array}$} \\
\hline Math & $\begin{array}{l}-0.92 \\
(3.33)\end{array}$ & $\begin{array}{c}3.60 \\
(3.93)\end{array}$ & $\begin{array}{c}3.32 \\
(2.96)\end{array}$ & $\begin{array}{l}-3.06 \\
(3.09)\end{array}$ & $\begin{array}{l}-1.36 \\
(2.18)\end{array}$ & $\begin{array}{l}-1.17 \\
(6.24)\end{array}$ & $\begin{array}{c}-6.43 \\
(12.11)\end{array}$ & $\begin{array}{l}-22.12 \\
(18.30)\end{array}$ \\
\hline Science & $\begin{array}{l}-0.18 \\
(3.25)\end{array}$ & $\begin{array}{c}2.68 \\
(3.55)\end{array}$ & $\begin{array}{c}3.11 \\
(3.01)\end{array}$ & $\begin{array}{l}-3.43 \\
(2.75)\end{array}$ & $\begin{array}{l}-1.95 \\
(1.83)\end{array}$ & $\begin{array}{l}-1.80 \\
(6.29)\end{array}$ & $\begin{array}{l}-11.30 \\
(9.37)\end{array}$ & $\begin{array}{l}-17.74 \\
(18.06)\end{array}$ \\
\hline Reading & $\begin{array}{l}-0.44 \\
(3.33) \\
\end{array}$ & $\begin{array}{c}4.00 \\
(3.99) \\
\end{array}$ & $\begin{array}{c}4.79 \\
(3.00) \\
\end{array}$ & $\begin{array}{l}-4.71 \\
(2.88)\end{array}$ & $\begin{array}{l}-2.80 \\
(1.82) \\
\end{array}$ & $\begin{array}{l}-1.18 \\
(6.36) \\
\end{array}$ & $\begin{array}{l}-13.38 \\
(10.94) \\
\end{array}$ & $\begin{array}{l}-20.04 \\
(18.20) \\
\end{array}$ \\
\hline \multicolumn{9}{|c|}{$\begin{array}{l}\text { School-level participation }(\%) \times \\
\text { school-mean SES }\end{array}$} \\
\hline Math & $\begin{array}{c}0.05 \\
(0.15)\end{array}$ & $\begin{array}{l}-0.16 \\
(0.19)\end{array}$ & $\begin{array}{c}0.07 \\
(0.11)\end{array}$ & $\begin{array}{l}-0.08 \\
(0.21)\end{array}$ & $\begin{array}{l}-0.12 \\
(0.08)\end{array}$ & $\begin{array}{c}0.03 \\
(0.21)\end{array}$ & $\begin{array}{l}-0.22 \\
(0.48)\end{array}$ & $\begin{array}{c}3.46 \\
(7.86)\end{array}$ \\
\hline Science & $\begin{array}{c}0.08 \\
(0.15)\end{array}$ & $\begin{array}{l}-0.08 \\
(0.18)\end{array}$ & $\begin{array}{c}0.02 \\
(0.09)\end{array}$ & $\begin{array}{c}0.02 \\
(0.20)\end{array}$ & $\begin{array}{l}-0.05 \\
(0.07)\end{array}$ & $\begin{array}{l}-0.07 \\
(0.18)\end{array}$ & $\begin{array}{l}-0.07 \\
(0.45)\end{array}$ & $\begin{array}{c}3.46 \\
(8.64)\end{array}$ \\
\hline Reading & $\begin{array}{c}0.12 \\
(0.17)\end{array}$ & $\begin{array}{c}0.02 \\
(0.18) \\
\end{array}$ & $\begin{array}{c}0.07 \\
(0.11) \\
\end{array}$ & $\begin{array}{l}-0.06 \\
(0.22)\end{array}$ & $\begin{array}{l}-0.03 \\
(0.08)\end{array}$ & $\begin{array}{l}-0.01 \\
(0.20)\end{array}$ & $\begin{array}{l}-0.05 \\
(0.46)\end{array}$ & $\begin{array}{c}0.71 \\
(9.66) \\
\end{array}$ \\
\hline \multicolumn{9}{|c|}{$\begin{array}{l}\text { School-level participation }(\%) \times \\
\text { within-school SES variation }\end{array}$} \\
\hline Math & $\begin{array}{l}-0.55 \\
(0.63)\end{array}$ & $\begin{array}{c}0.45 \\
(0.44)\end{array}$ & $\begin{array}{l}-0.13 \\
(0.51)\end{array}$ & $\begin{array}{c}0.29 \\
(0.54)\end{array}$ & $\begin{array}{l}-0.04 \\
(0.32)\end{array}$ & $\begin{array}{l}-0.44 \\
(0.84)\end{array}$ & $\begin{array}{c}0.02 \\
(2.02)\end{array}$ & - \\
\hline Science & $\begin{array}{l}-0.56 \\
(0.61)\end{array}$ & $\begin{array}{c}0.38 \\
(0.40)\end{array}$ & $\begin{array}{c}0.40 \\
(0.38)\end{array}$ & $\begin{array}{l}-0.05 \\
(0.47)\end{array}$ & $\begin{array}{l}-0.25 \\
(0.30)\end{array}$ & $\begin{array}{l}-0.09 \\
(0.75)\end{array}$ & $\begin{array}{l}-0.40 \\
(1.72)\end{array}$ & - \\
\hline Reading & $\begin{array}{c}0.42 \\
(0.34)\end{array}$ & $\begin{array}{c}0.07 \\
(0.23)\end{array}$ & $\begin{array}{c}0.09 \\
(0.14)\end{array}$ & $\begin{array}{l}-0.08 \\
(0.41)\end{array}$ & $\begin{array}{c}0.06 \\
(0.25)\end{array}$ & $\begin{array}{l}-0.38 \\
(0.26)\end{array}$ & $\begin{array}{c}0.21 \\
(0.49)\end{array}$ & - \\
\hline
\end{tabular}

Note. The table shows a coefficient and standard errors in parentheses for the corresponding interaction term from a separate regression model. The interaction term between school-level participation and within-school SES variation in Macao is omitted due to a dependency among predictors. Significance level: ${ }^{*} \mathrm{p}<0.10 ;{ }^{* *}$ $\mathrm{p}<0.05 ; * * * \mathrm{p}<0.01$.

I found no statistically significant interaction effects for any of the subjects and in any of the countries and economies. The results indicate that the association between participation of a student's own parents and student achievement does not change according to the level of the parents' SES. Similarly, the association between school-level participation and student achievement does not vary by either the level or the variation of parents' SES within the school (Note 4).

\subsection{School's Openness to Parental Engagement as a Moderating Factor}

Given the lack of moderating effects of SES, I explored other factors that may have moderated the participation-achievement association. Parent participation might be effectively leveraged for improving student achievement when schools recognize the importance of parent engagement and promote it proactively. Such schools may provide a welcoming and supportive environment that enables parents who participate in school management to obtain information and networks useful to strengthen learning support at home and/or play an active role in school decision-making. Therefore, I examined whether school's openness to parental engagement moderates the participation-achievement association. I used factor analysis to generate latent variables that measure school's openness to parental engagement from a set of questions that asked parents to assess their 
school's parental engagement practices. The first factor, which accounts for $62 \%$ of the total variation (Note 5), was interacted with individual-level parent participation, and the school-mean parents' perception was interacted with school-level parent participation, respectively, in separate models. The results are presented in Table 5.

Table 5. Interaction effects between parent participation in school management and parents' perception of school's openness to parental engagement

\begin{tabular}{|c|c|c|c|c|c|c|c|c|}
\hline \multirow{2}{*}{$\begin{array}{l}\text { Main effects and } \\
\text { Interaction term }\end{array}$} & \multicolumn{8}{|c|}{ Test score } \\
\hline & Croatia & Georgia & Portugal & $\begin{array}{c}\text { Dom. } \\
\text { Republic }\end{array}$ & Mexico & Korea & Hong Kong & Macao \\
\hline \multicolumn{9}{|c|}{ 1) Individual-level participation $\times$ parent's perception of school's openness to parental engagement } \\
\hline Parent participation & $\begin{array}{c}-9.72 * * * \\
(3.21)\end{array}$ & $\begin{array}{l}-0.46 \\
(4.42)\end{array}$ & $\begin{array}{l}-1.29 \\
(4.18)\end{array}$ & $\begin{array}{l}-6.57 * * \\
(3.29)\end{array}$ & $\begin{array}{l}-0.74 \\
(2.51)\end{array}$ & $\begin{array}{l}-5.41 \\
(5.30)\end{array}$ & $\begin{array}{c}6.34 \\
(16.09)\end{array}$ & $\begin{array}{c}12.37 \\
(19.13)\end{array}$ \\
\hline $\begin{array}{l}\text { Parent participation } \times \text { parent's } \\
\text { perception }\end{array}$ & $\begin{array}{l}-3.60 \\
(2.85)\end{array}$ & $\begin{array}{l}-0.05 \\
(3.95)\end{array}$ & $\begin{array}{l}-1.66 \\
(3.65)\end{array}$ & $\begin{array}{l}-1.94 \\
(2.19)\end{array}$ & $\begin{array}{l}-1.56 \\
(1.99)\end{array}$ & $\begin{array}{l}-2.12 \\
(6.17)\end{array}$ & $\begin{array}{c}6.02 \\
(20.51)\end{array}$ & $\begin{array}{l}-38.07 * * \\
(16.30)\end{array}$ \\
\hline \multicolumn{9}{|l|}{ Science } \\
\hline Parent participation & $\begin{array}{c}-9.10 * * * \\
(2.76)\end{array}$ & $\begin{array}{l}-4.62 \\
(3.81)\end{array}$ & $\begin{array}{l}-3.69 \\
(4.64)\end{array}$ & $\begin{array}{c}-6.47 * * \\
(3.23)\end{array}$ & $\begin{array}{l}-4.09 * \\
(2.13)\end{array}$ & $\begin{array}{l}-6.10 \\
(4.89)\end{array}$ & $\begin{array}{c}4.48 \\
(15.80)\end{array}$ & $\begin{array}{c}8.16 \\
(17.72)\end{array}$ \\
\hline $\begin{array}{l}\text { Parent participation } \times \text { parent's } \\
\text { perception }\end{array}$ & $\begin{array}{l}-4.43 \\
(2.91)\end{array}$ & $\begin{array}{c}0.43 \\
(3.90)\end{array}$ & $\begin{array}{c}0.31 \\
(3.30)\end{array}$ & $\begin{array}{l}-2.81 \\
(2.54)\end{array}$ & $\begin{array}{l}-0.74 \\
(1.97)\end{array}$ & $\begin{array}{l}-2.48 \\
(6.09)\end{array}$ & $\begin{array}{c}1.60 \\
(19.20)\end{array}$ & $\begin{array}{c}-47.81 * * * \\
(15.96)\end{array}$ \\
\hline$\underline{\text { Reading }}$ & & & & & & & & \\
\hline Parent participation & $\begin{array}{c}-9.73 * * * \\
(3.02)\end{array}$ & $\begin{array}{l}-4.26 \\
(4.75)\end{array}$ & $\begin{array}{l}-3.39 \\
(4.01)\end{array}$ & $\begin{array}{l}-7.17 * \\
(3.92)\end{array}$ & $\begin{array}{l}-4.59 * \\
(2.45)\end{array}$ & $\begin{array}{l}-8.66^{*} \\
(4.97)\end{array}$ & $\begin{array}{c}0.86 \\
(16.85)\end{array}$ & $\begin{array}{c}-4.39 \\
(18.93)\end{array}$ \\
\hline $\begin{array}{l}\text { Parent participation } \times \text { parent's } \\
\text { perception }\end{array}$ & $\begin{array}{l}-4.87 \\
(3.05)\end{array}$ & $\begin{array}{r}1.30 \\
(4.05)\end{array}$ & $\begin{array}{l}-1.18 \\
(3.64)\end{array}$ & $\begin{array}{l}-1.48 \\
(2.81)\end{array}$ & $\begin{array}{l}-0.22 \\
(2.17)\end{array}$ & $\begin{array}{l}-4.91 \\
(5.32)\end{array}$ & $\begin{array}{c}5.04 \\
(20.00)\end{array}$ & $\begin{array}{c}-38.07 * * \\
(15.52)\end{array}$ \\
\hline \multicolumn{9}{|c|}{$\begin{array}{l}\text { 2) School-level participation } \times \text { school-mean parents 'perception of school's openness to parental engagement } \\
\text { Math }\end{array}$} \\
\hline $\begin{array}{l}\text { School-level parent } \\
\text { participation }(\%)\end{array}$ & $\begin{array}{c}0.03 \\
(0.07)\end{array}$ & $\begin{array}{c}-0.27 * * \\
(0.11)\end{array}$ & $\begin{array}{l}-0.08 \\
(0.07)\end{array}$ & $\begin{array}{l}-0.07 \\
(0.10)\end{array}$ & $\begin{array}{c}0.04 \\
(0.08)\end{array}$ & $\begin{array}{c}0.10 \\
(0.10)\end{array}$ & $\begin{array}{c}0.07 \\
(0.45)\end{array}$ & $\begin{array}{l}-1.76 \\
(4.13)\end{array}$ \\
\hline $\begin{array}{l}\text { Participation } \quad(\%) \quad \times \\
\text { school-mean } \\
\text { perception } \\
\text { Science }\end{array}$ & $\begin{array}{l}-0.28 \\
(0.29)\end{array}$ & $\begin{array}{c}0.03 \\
(0.18)\end{array}$ & $\begin{array}{c}0.22 \\
(0.25)\end{array}$ & $\begin{array}{l}0.22 * \\
(0.13)\end{array}$ & $\begin{array}{c}0.05 \\
(0.18)\end{array}$ & $\begin{array}{l}-0.02 \\
(0.34)\end{array}$ & $\begin{array}{l}-0.07 \\
(0.59)\end{array}$ & - \\
\hline $\begin{array}{l}\text { School-level } \\
\text { participation (\%) }\end{array}$ & $\begin{array}{c}0.03 \\
(0.07)\end{array}$ & $\begin{array}{l}-0.15 \\
(0.10)\end{array}$ & $\begin{array}{l}-0.02 \\
(0.05)\end{array}$ & $\begin{array}{l}-0.08 \\
(0.09)\end{array}$ & $\begin{array}{c}0.01 \\
(0.07)\end{array}$ & $\begin{array}{c}0.19^{* *} \\
(0.10)\end{array}$ & $\begin{array}{c}0.08 \\
(0.39)\end{array}$ & $\begin{array}{l}-0.52 \\
(3.16)\end{array}$ \\
\hline $\begin{array}{l}\text { Participation } \\
\text { school-mean } \\
\text { perception }\end{array}$ & $\begin{array}{l}-0.24 \\
(0.29)\end{array}$ & $\begin{array}{l}-0.11 \\
(0.16)\end{array}$ & $\begin{array}{l}0.36^{*} \\
(0.21)\end{array}$ & $\begin{array}{c}0.19 \\
(0.13)\end{array}$ & $\begin{array}{c}0.08 \\
(0.16)\end{array}$ & $\begin{array}{c}0.35 \\
(0.30)\end{array}$ & $\begin{array}{l}-0.11 \\
(0.52)\end{array}$ & - \\
\hline Reading & & & & & & & & \\
\hline $\begin{array}{l}\text { School-level } \\
\text { participation (\%) }\end{array}$ & $\begin{array}{c}0.05 \\
(0.07)\end{array}$ & $\begin{array}{l}-0.02 * \\
(0.11)\end{array}$ & $\begin{array}{l}-0.02 \\
(0.07)\end{array}$ & $\begin{array}{l}-0.22 * \\
(0.11)\end{array}$ & $\begin{array}{c}0.01 \\
(0.08)\end{array}$ & $\begin{array}{c}0.14 \\
(0.10)\end{array}$ & $\begin{array}{c}0.02 \\
(0.34)\end{array}$ & $\begin{array}{l}-2.09 \\
(3.45)\end{array}$ \\
\hline $\begin{array}{l}\text { Participation } \\
\text { school-mean } \\
\text { perception }\end{array}$ & $\begin{array}{l}-0.33 \\
(0.36)\end{array}$ & $\begin{array}{l}-0.02 \\
(0.18)\end{array}$ & $\begin{array}{c}0.32 \\
(0.23)\end{array}$ & $\begin{array}{c}0.36^{* *} \\
(0.15)\end{array}$ & $\begin{array}{c}0.08 \\
(0.18)\end{array}$ & $\begin{array}{c}0.09 \\
(0.35)\end{array}$ & $\begin{array}{c}0.02 \\
(0.52)\end{array}$ & - \\
\hline
\end{tabular}

Note. The table shows a coefficient and standard errors in parentheses for parent participation (main effects) and a corresponding interaction term. The interaction term in specification 2 in Macao is omitted due to a dependency among predictors. All models include individual- and school-level parent participation measures, parents' SES, student and school characteristics, and additional controls addressing potential sources of endogeneity. Significance level: ${ }^{*} \mathrm{p}<0.10 ; * * \mathrm{p}<0.05 ; * * * \mathrm{p}<0.01$

In Macao, there are negative interaction effects for the association between individual-level parent participation and student achievement. This indicates that parents who felt more involved by their child's school received fewer benefits from their own participation or paid a greater cost of participation in terms of student achievement. For instance, participation of a student's own parents is associated with a 17.55-point increase in mathematics scores 
for students whose parents have an average level of perception about the school's openness $(-0.14)$. However, for parents whose perception is one standard deviation higher than the average (0.77), their participation is associated with a decrease in mathematics scores by 17.08 points.

In the Dominican Republic, the results show small but positive interaction effects for the association between school-level parent participation and students' reading scores. In schools where parents' perception about their school's openness is at the country's average (0.64), a 10-percentage-point increase in the proportion of parents who participate in school management is associated with an increase in reading achievement by 0.11 points. However, in schools where the parents' perception is one standard deviation higher than the country average (1.05), a 10-percentage-point increase in the share of participating parents is associated with an increase in reading scores by 1.59 points.

\section{Limitations}

The findings of this study need to be interpreted with several limitations in mind. First, the analyses may still be subject to biases resulting from endogeneity. Even though the models controlled for potential sources of endogeneity, there might be other factors that explain both parent participation and student achievement. Therefore, no causal inference can be made from the findings of this study.

Second, the school-level participation measure may be subject to measurement error. This study used a school-reported share of parents participating in school management as a measure of school-level parent participation. However, the information provided by schools might not necessarily be accurate if the data did not come from official school records.

Third, the PISA survey did not provide the information on types of school governing bodies and decision-making tasks in which parents were actually engaged. Therefore, the results of this study might be influenced by the variation in types of school governing bodies and the degree of decision-making authority accorded to parents.

\section{Discussion and Conclusion}

This study examined how individual-level and school-level parent participation in school management, each of which would have a distinct mechanism for learning gain, is associated with student achievement in eight countries and economies. The analysis shows that the participation-achievement association varies by country and economy but any statistically significant associations lie in a negative direction. However, depending on the country or economy, the negative associations are identified in either participation of a student's own parents that is more likely to affect home input or participation of a group of parents that is assumed to affect school input. This study also found that the participation-achievement associations are not moderated by parents' SES but by the parents' perception of school's openness to parental engagement in some countries and economies. I discuss these findings in specific country contexts and provide insights into participatory school governance.

\subsection{Participation of Student's Own Parents}

The literature suggests that parents obtain information and networks that can be utilized to strengthen their learning support at home through their participation in school management (Hill \& Taylor, 2004; McNeal, 1999). However, participation of a student's own parents was found not to be associated with student achievement in most of the countries and economies. One potential explanation could be that the resources obtained at school did not contribute to increasing the quality of learning support at home. The descriptive analysis presented in Table 2 indicated that parents who participated in school management cared about their child's education and academic success more than non-participating parents. This implies that participating parents might have already provided an optimal level of learning support even before their participation in school management.

However, this hypothesis does not explain the negative associations found in Croatia, the Dominican Republic, and Mexico. The negative associations suggest that parents who participated in school management might have ended up providing a lower level of home input. This could happen if, for example, parents who had provided relatively high-level learning support at home had to cut the amount of their support as a result of participating in school management and were unable to obtain useful resources to strengthen their learning support. In other words, the negative association could be explained by high opportunity cost and insufficient benefits of participation.

In fact, the opportunity cost of participation is considered relatively high in these countries. According to the PISA data, parents of public school students in the Dominican Republic, Croatia, and Mexico rank 1st, 5th, and 6th out of 17 countries and economies in terms of the frequency of helping their child with homework. By devoting their time to school management, however, they may have given up some amount of learning support at home. In addition, the benefits of participating in school management for individual parents would be low, at least, in 
Croatia. According to Pahić et al. (2010), in Croatia, only parents who truly engaged in the work of school boards realized that their participation was useful for their own child (as cited in Ercegovac, Koludrović, \& Bubić, 2016). These imply that, if a negative association is derived from individual-level participation, policy makers may need to develop more efficient participatory school governance from which parents can obtain useful information and networks with less time commitment into school management tasks.

\subsection{Participation of a Group of Parents}

The literature suggests that parents who have direct incentives to improve their child's education would seek to influence school decisions to improve the learning environment at school through their participation in school management (e.g., Barrera-Osorio et al., 2009; Epstein, 1995). However, school-level parent participation was found not to be associated with student achievement in most of the countries and economies.

One potential explanation would be a relatively weak sense of urgency to improve the quality of school education among parents who participated in school management. As presented in Table 2, participating parents had a greater level of satisfaction with the quality of their child's school than non-participating parents. This implies that parents might not have exerted influence over school decision-making even if they participated in school management because they were already content with education provided at their child's school.

One unique case is Georgia, where the proportion of parents participating in school management is negatively associated with student achievement. The finding implies that allowing a large number of parents to influence school decision-making might have caused detrimental effects on school operation and students' learning. In fact, the literature suggests that, although participatory school boards were introduced in the country during the 2000s, schools were not properly prepared to engage parents in school decision-making due to insufficient capacity as well as corruption and chaos in school governance resulting from frequent changes in the country's decentralization policy (Dzotsenidze, 2018; Gorgodze, 2016; The World Bank, 2014). In such circumstances, engaging parents who are not education professionals in school decision-making might have reduced school effectiveness. This suggests that, if a negative association is derived from school-level participation, policy makers may need to provide parents with an enabling environment so that they can play an effective role in school decision-making.

\subsection{Factors Moderating the Participation-Achievement Association}

This study found that parents' SES did not moderate the participation-achievement association for both individual-level and school-level participation. The results imply that parents' SES did not affect either the parents' ability to capitalize upon their own participation to strengthen their learning support at home or the parents' power to influence school decisions to improve learning environments at school through their participation in school management. However, the study found that the parents' perception of school's openness to parental engagement did moderate the participation-achievement association in Macao and the Dominican Republic.

In Macao, the negative interaction effects for individual-level parent participation suggest that parents who felt strongly involved by the school might have paid the higher opportunity cost of participation, indicating that what matters may not be participation per se but a degree of involvement. In Macao, the roles of parents and school tend to be defined by a clear demarcation of tasks with parents as home-based supporters and teachers as school-based educators (Ho, 2009). Therefore, parents with trust in the school express a low level of desire to influence school decisions (Chou, 2012; Ho, 2009). Under this circumstance, it is likely that parents tend to volunteer a minimum level of commitment to school management even if they participate in a school governing body. In such cases, the opportunity cost of participation is assumed to increase only when participating parents are actively involved in school management with substantial time commitment. This speculative explanation can only be confirmed if there are data on not only the state of parent participation but also on the degree of their involvement.

In the Dominican Republic, the positive interaction effects for school-level parent participation indicate that a group of parents who felt strongly welcomed and involved by the school could be more likely to influence school decisions in a way to improve reading achievement through their participation in school management. Unfortunately, a scarcity of literature on parent participation in the country poses a challenge in exploring the reason behind this finding.

\subsection{Conclusion}

Strengthening school-parent partnerships is recognized as a strategy for improving the quality of school education and holding schools accountable for learning outcomes. However, the results of this study indicate that parent participation in school management might not necessarily be a promising strategy for improving the quality of education and educational outcomes. 
The findings of this study call into question the recommendations to increase parental participation in school management without attending to various contextual factors. This study relays the importance of identifying mechanisms that account for participation-achievement associations in each country and key conditions under which parent participation can effectively increase home and school input. Establishing a better understanding of how parent participation works in a given context helps policy makers and school authorities to leverage the school-parent partnerships for improving students' learning outcomes.

\section{Acknowledgements}

I thank Dr. Amita Chudgar, Dr. Lynn Paine, Dr. David Arsen, and Dr. Joshua Cowen at Michigan State University for their valuable comments and suggestions.

\section{References}

Anderson, D. (1992). The interaction of public and private school systems. Australian Journal of Education, 36(3), 213-236. https://doi.org/10.1177/000494419203600302

Anderson, G. L. (1998). Toward authentic participation: Deconstructing the discourses of participatory reforms in education. American Educational Research Journal, 35(4), 571-603. https://doi.org/10.3102/00028312035004571

Barrera-Osorio, F., Fasih, T., Patrinos, H. A. (2009). Decentralized decision-making in schools: The theory and evidence on school-based management. Washington, DC: The World Bank.

Bruns, B., Filmer, D., \& Patrinos, H. A. (2011). Making schools work: New evidence on accountability reforms. Washington, DC: The World Bank. https://doi.org/10.1596/978-0-8213-8679-8

Chaudhury, N., \& Parajuli, D. (2010). Giving it back: Evaluating the impact of devolution of school management to communities in Nepal. Unpublished manuscript, The World Bank, Washington, DC.

Chikoko, V. (2008). The role of parent governors in school governance in Zimbabwe: Perceptions of school heads, teachers, and parents. International Review of Education, 54(2), 243-263. https://doi.org/10.1007/s11159-007-9080-x

Chou, B. K. P. (2012). The paradox of educational quality and education policy in Hong Kong and Macau. Chinese Education and Society, 45(2), 96-110. https://doi.org/10.2753/CED1061-1932450206

Dearing, E., Kreider, H., Simpkins, S., \& Weiss, H. B. (2006). Family involvement in school and low-income children's literacy: Longitudinal associations between and within families. Journal of Educational Psychology, 98(4), 653-664. https://doi.org/10.1037/0022-0663.98.4.653

Desimone, L. (1999). Linking parent involvement with student achievement: Do race and income matter? The Journal of Educational Research, 93(1), 11-30. https://doi.org/10.1080/00220679909597625

Domina, T. (2005). Leveling the home advantage: Assessing the effectiveness of parental involvement in elementary school. Sociology of Education, 78, 233-249. https://doi.org/10.1177/003804070507800303

Dzotsenidze, N. (2018). The school decentralization process in Georgia and South Africa through the lens of world culture theory: A comparative analysis. In A. W. Wiseman, \& P. M. Davidson (Eds.), Cross-nationally comparative, evidence-based educational policy making and reform (pp. 101-124). Bingley: Emerald Publishing. https://doi.org/10.1108/S1479-367920180000035005

Edwards, D. B., Jr., \& DeMatthews, D. E. (2014). Historical trends in educational decentralization in the United States and developing countries: A periodization and comparison in the post-WWII context. Education Policy Analysis Archives, 22(40), 1-35. https://doi.org/10.14507/epaa.v22n40.2014

Epstein, J. L. (1995). School/family/community partnerships: Caring for the children we share. Phi Delta Kappan, 76(9), 701-712.

Ercegovac, I. R., Koludrović, M., \& Bubić, A. (2016). School governance models and school boards: Educational and administrative aspects. In N. Alfirević, J. Burušić, J. Pavičić, \& R. Relja (Eds.), School effectiveness and educational management: Towards a south-eastern Europe research and public policy agenda (pp. 107-124). Cham: Palgrave Macmillan. https://doi.org/10.1007/978-3-319-29880-1_7

Fan, X. (2001). Parental involvement and students' academic achievement: A growth modeling analysis. Journal of Experimental Education, 70(1), 27-61. https://doi.org/10.1080/00220970109599497

Galiani, S., Gertler, P., \& Schargrodsky, E. (2008). School decentralization: Helping the good get better, but leaving the poor behind. Journal of Public Economics 92(10-11), 2106-2120. 
https://doi.org/10.1016/j.jpubeco.2008.05.004

Gershberg, A. I., Meade, B., \& Andersson, S. (2009). Providing better education services to the poor: Accountability and context in the case of Guatemalan decentralization. International Journal of Educational Development, 29(3), 187-200. https://doi.org/10.1016/j.ijedudev.2008.08.002

Gorgodze, S. (2016). Rise and fall of decentralized school governance - Decision-making practices in Georgia. International Education Studies, 9(11), 25-39. https://doi.org/10.5539/ies.v9n11p25

Hill, N. E. \& Taylor, L. C. (2004). Parental school involvement and children's academic achievement: Pragmatics and issues. Current Directions in Psychological Science, 13(4), 161-164. https://doi.org/10.1111/j.0963-7214.2004.00298.x

Ho, E. S. C. (2009). Home-school collaboration in two Chinese societies: Hong Kong and Macao. In R. Deslandes (Ed.), International perspectives on contexts, communities and evaluated innovative practices: Family-school-community partnerships (pp. 37-49). New York: Routledge.

Iftene, C. (2014). Educational systems' autonomy: Facts and analysis. Procedia-Social and Behavioral Sciences, 142, 47-53. https://doi.org/10.1016/j.sbspro.2014.07.586

Kaiser, H. F. (1960). The application of electronic computers to factor analysis. Educational and Psychological Measurement. 20, 141-151. https://doi.org/10.1177/001316446002000116

Khan, S. R. (2003). Participation via collective action in government and NGO schools in Pakistan. Development in Practice, 13(4), 361-376. https://doi.org/10.1080/09614520320001122419

Lee, J. H., \& Huber, J., Jr. (2011). Multiple imputation with large proportions of missing data: How much is too mисh? United Kingdom Stata Users' Group Meetings 2011 23, Stata Users Group.

McNeal, R. B., Jr. (1999). Parental involvement as social capital: Differential effectiveness on science achievement, truancy, and dropping out. Social Forces 78(1), 117-144. https://doi.org/10.1093/sf/78.1.117

McNeal, R. B., Jr. (2012). Checking in or checking out? Investigating the parent involvement reactive hypothesis. The Journal of Educational Research, 105(2), 79-89. https://doi.org/10.1080/00220671.2010.519410

Moradi, S., Beidokhti, A. A., \& Fathi, K. (2016). Comparative comparison of implementing school-based management in developed countries in the historical context: From theory to practice. International Education Studies, 9(9), 191-198. https://doi.org/10.5539/ies.v9n9p191

Muskin, J. A. (1999). Including local priorities to assess school quality: The case of Save the Children Community Schools in Mali. Comparative Education Review, 43(1), 36-63. https://doi.org/10.1086/447544

OECD. (2009). PISA data analysis manual: SPSS ${ }^{\circledR}$ (2nd ed.). Paris: OECD Publishing.

OECD. (2017a). PISA-based test for schools: Technical report 2016. Paris: OECD Publishing.

OECD. (2017b). PISA 2015 technical report. Paris: OECD Publishing.

Park, S., \& Holloway, S. D. (2017). The effects of school-based parental involvement on academic achievement at the child and elementary school level: A longitudinal study. The Journal of Educational Research, 110(1), 1-16. https://doi.org/10.1080/00220671.2015.1016600

Ponce, J. (2006). The impact of a school-based management program on students' cognitive achievement: A case study of Redes Amigas in rural Ecuador. FLASCO-Ecuador.

San Antonio, D. M. (2008). Creating better schools through democratic school leadership. International Journal of Leadership in Education, 11(1), 43-62. https://doi.org/10.1080/13603120601174311

Santibañez, L., Abreu-Lastra, R., \& O’Donoghue, J. (2014). School based management effects: Resources or governance change? Evidence from Mexico. Economics of Education Review, 39, 97-109. https://doi.org/10.1016/j.econedurev.2013.11.008

Shatkin, G., \& Gershberg, A. I. (2007). Empowering parents and building communities: The role of school-based councils in educational governance and accountability. Urban Education, 42(6), 582-615. https://doi.org/10.1177/0042085907305044

Shumow, L., \& Miller, J. D. (2001). Parents' at-home and at-school academic involvement with young adolescents. The Journal of Early Adolescence, 21, 68-91. https://doi.org/10.1177/0272431601021001004

StataCorp. (2017). Stata multiple-imputation reference manual: Release 15. College Station, TX: A Stata Press publication. 
Sui-Chu, E. H., \& Willms, J. D. (1996). Effects of parental involvement on eighth-grade achievement. Sociology of Education, 69(2), 126-141. https://doi.org/10.2307/2112802

Swift-Morgan, J. (2006). What community participation in schooling means: Insights from Southern Ethiopia. Harvard Education Review, 76(3), 339-368. https://doi.org/10.17763/haer.76.3.e475j32j69q27x63

The World Bank. (2014). Georgia: Technical assistance to support preparation of education sector strategy: Education sector policy review: Strategic issues and reform agenda. Washington, DC: The World Bank.

UNESCO. (2008). EFA Global Monitoring Report 2009. Overcoming inequality: Why governance matters. Paris: UNESCO Publishing.

UNESCO. (2013). The global learning crisis: Why every child deserves a quality education. Paris: UNESCO.

UNESCO. (2015a). Education 2030: Incheon declaration and framework for action for the implementation of Sustainable Development Goal 4. Paris: UNESCO.

UNESCO. (2015b). EFA Global Monitoring Report 2015. Education for all 2000-2015: Achievements and challenges. Paris: UNESCO Publishing.

UNESCO Institute for Statistics. (2018). UIS.Stat. Montreal: UNESCO Institute for Statistics. Retrieved from http://data.uis.unesco.org

\section{Notes}

Note 1. Multiple imputations generate bias that increases as the proportion of missing data increases if the probability of a particular value being missing depends on unobserved data (Lee \& Huber, 2011). Because I could not eliminate a possibility that the missing mechanism is missing not at random (MNAR), I dropped countries with more than $10 \%$ missing data.

Note 2. The PISA 2015 round provides 10 plausible values for test scores to improve the accuracy of estimation. The analysis using plausible values was performed in accordance with the PISA Analytical Manual (OECD, 2009).

Note 3. Only the first factor was retained in accordance with the Kaiser criterion (Kaiser, 1960).

Note 4. The results did not change even if I used the SES of parents who actually participated in school management instead of the SES of all parents in school.

Note 5. Only the first factor was retained in accordance with the Kaiser criterion (Kaiser, 1960).

\section{Appendix A}

\section{List of Variables}

\begin{tabular}{|c|c|}
\hline Variable & Definition \\
\hline \multicolumn{2}{|l|}{$\underline{\text { Outcomes }}$} \\
\hline Student achievement & Test scores in mathematics, science, and reading. \\
\hline \multicolumn{2}{|l|}{$\underline{\text { Parent participation }}$} \\
\hline $\begin{array}{l}\text { Participation of a student's own parents in } \\
\text { school management }\end{array}$ & Parents' report on whether they participated in local school government. \\
\hline $\begin{array}{l}\text { A proportion of parents who participate in } \\
\text { school management }\end{array}$ & $\begin{array}{l}\text { School's report on a proportion of parents who participated in local school } \\
\text { government. }\end{array}$ \\
\hline \multicolumn{2}{|l|}{$\underline{\text { Student characteristics }}$} \\
\hline Parents' socioeconomic status & $\begin{array}{l}\text { PISA SES index derived from parents' education, highest occupation, and home } \\
\text { possessions. }\end{array}$ \\
\hline Age & Age in month. \\
\hline Female & Whether the student is female. \\
\hline Native immigration status & Whether at least one parent was born in the country. \\
\hline Home/test language match & Whether the test language is the same as home language. \\
\hline Relative school grade & $\begin{array}{l}\text { A difference from the modal grade at which the majority of } 15 \text {-year-old students } \\
\text { are enrolled. }\end{array}$ \\
\hline School program & School program (general, pre-vocational, or vocational). \\
\hline \multicolumn{2}{|l|}{$\underline{\text { School characteristics }}$} \\
\hline School location & The population in a community where school is located in five categories. \\
\hline
\end{tabular}




\section{School size}

Controls for endogeneity

Parents' academic orientation (individual-level)

Parents' academic orientation (school-level)

Parents discussing progress with a teacher on one's own initiative (individual-level)

Parents discussing progress with a teacher on their own initiative (school-level)

Whether school involves parents in decision-making

$\underline{\text { Variables for interaction }}$

School-level SES

Within-school variation in SES

Parents' perception of school's openness to parent engagement (individual-level)

Parents' perception of school's openness to parent engagement (school-level)

Parents' characteristics

Reason for school choice:

- Good reputation

Reason for school choice:

- Courses offered

Reason for school choice:

- High achievement

Satisfaction with school quality
School enrollment.

The factor score derived from the three variables, which asked parents the importance of reasons for choosing a school for their child in a four-point scale (1. good reputation; 2 . course/subjects; and 3. student achievement).

School average of the above factor score, excluding the score of a student's own parents from calculation.

Parents' report on whether they discussed progress with a teacher on their own initiative.

School report on a share of parents who discussed progress with a teacher on their own initiative.

School report on whether school involves parents in decision-making.

School-mean SES of parents, excluding SES of a student's own parents from calculation.

Within-school standard deviation in SES of parents.

The factor score derived from the five variables, which asked parents their perception of schools' parental engagement practices in a four-point scale (1. providing an inviting atmosphere; 2 . providing effective school-home communication; 3. involving in decision-making; 4. providing regular information on child's progress; and 5. informing about how to help child's homework and school activities).

School average of the above factor score on parent's perception of schools' parental engagement practices.

The importance of a good reputation as a reason for choosing a school for their child in a four-point scale.

The importance of offering of particular courses or subjects as a reason for choosing a school for their child in a four-point scale.

The importance of high academic achievement as a reason for choosing a school for their child in a four-point scale.

The PISA index of parents' perceptions of the quality of school learning

\section{Copyrights}

Copyright for this article is retained by the author(s), with first publication rights granted to the journal.

This is an open-access article distributed under the terms and conditions of the Creative Commons Attribution license (http://creativecommons.org/licenses/by/4.0/). 